\title{
Rescue from dominant follicle atresia by follicle-stimulating hormone in mice
}

\author{
X.L. Zhou, Y. Teng, R. Cao, H. Fu, K. Xiong, W.X. Sun, C.C. Zhu, \\ X.J. Huang, P. Xiao and H.L. Liu \\ College of Animal Science and Technology, Nanjing Agricultural University, \\ Nanjing, China \\ Corresponding author: H.L. Liu \\ E-mail: liuhonglin@njau.edu.cn \\ Genet. Mol. Res. 12 (3): 2945-2952 (2013) \\ Received August 28, 2012 \\ Accepted March 26, 2013 \\ Published August 12, 2013 \\ DOI http://dx.doi.org/10.4238/2013.August.12.10
}

\begin{abstract}
We investigated the effects of follicle-stimulating hormone (FSH) on atresia of the dominant follicle and changes in relevant apoptosis genes in granulosa cells of dominant follicles regulated by FSH in vivo. Four-week-old mice were administered FSH by intraperitoneal injection to induce follicular maturation. Granulosa cells of dominant follicles were collected at 48, 72, and $96 \mathrm{~h}$ after the first FSH injection. Phosphate-buffered saline was injected as a control. The mRNA levels of relevant granulosa cell apoptosis genes were examined by real-time quantitative polymerase chain reaction, and apoptosis of granulosa cells in dominant ovarian follicles was determined by the terminal deoxynucleotidyl transferase dUTP nick-end labeling (TUNEL) assay. Apoptosis in granulosa cells of dominant follicles was almost TUNEL-negative at 48, 72-66, 72, and 96-90 $\mathrm{h}$ after the first FSH injection, but granulosa cell apoptosis in dominant follicles was clearly detected at 96,102 , and $102-96$ h by TUNEL. The BIM, caspase-3, and caspase-9 mRNA expression levels were significantly lower after FSH treatment at 72-66 and 96-90 h, compared with that at 72 and $96 \mathrm{~h}(\mathrm{P}<0.05)$. Caspase-8 and FasL mRNA expressions did not respond to FSH. FSH rescued granulosa cells from apoptosis when the relevant apoptosis genes were upregulated in early atretic follicles. FSH did not rescue granulosa cells from apoptosis if the DNA was cut
\end{abstract}


into fragments by endonucleases. Thus, the rescue by FSH of granulosa cells from apoptosis and dominant follicle atresia may be accomplished by inhibition of apoptosis in mitochondria.

Key words: Follicle-stimulating hormone; Granulosa cells; Follicular atresia; Mitochondrial apoptosis

\section{INTRODUCTION}

Most mammalian follicles undergo atresia before ovulation, which can occur at various stages (Kaipia and Hsueh, 1997; Jiang et al., 2003). It is clear that granulosa cell apoptosis is the major cause of antral and dominant follicular atresia (Manabe et al., 2008; Sai et al., 2011); however, the mechanism of granulosa cell apoptosis remains unclear.

Follicle-stimulating hormone (FSH) rescues follicles from atresia (Layman and McDonough, 2000). FSH is believed to be the most important survival factor inhibiting granulosa cell apoptosis and can rescue granulosa cells from apoptosis in porcine and bovine (Yang and Rajamahendran, 2000; Asahara et al., 2003). The hormone is also necessary and adequate to induce maturation of ovarian follicles, resulting in the generation of mature eggs and the production of estrogens (Hunzicker-Dunn and Maizels, 2006). Sufficient estrogens are needed by dominant follicles for ovulation (Manabe et al., 1996).

Programmed cell-death (PCD) is the death of cells in any form, mediated by an intracellular program (Schwartz et al., 1993; Engelberg-Kulka et al., 2006). PCD occurs through the death receptor pathway, the mitochondrial apoptotic pathway, and necrotic cell death (Smith and Yellon, 2011). Besides these 3 types of PCD, another pathway called necroptosis (or caspase-independent programmed cell death) has been discovered (Kroemer and Martin, 2005). The Fas receptor binds the Fas ligand (FasL), a transmembrane protein, which is part of the tumor necrosis factor family (Wajant, 2002). The interaction between Fas and FasL results in the formation of the death-inducing signaling complex, which contains Fas-associated protein with death domain, caspase- 8 , and caspase- 10 . Processed caspase- 8 directly activates caspase- 3 and triggers the execution of apoptosis in the cell (Berry, 2007). The release of cytochrome $c$ from the mitochondria into the cytosol is regulated by members of the BCL-2 family through their ability to influence mitochondrial integrity (Hengartner, 2000). BIM (Bcl2111), a gene that encodes a member of the pro-apoptotic BH3-only subgroup of BCL-2 family proteins, functions in the intrinsic mitochondrial apoptotic pathway (Gilley et al., 2003).

In this study, we investigated the mechanisms of FSH action on granulosa cell apoptosis in dominant mouse follicles and identified the pathways involved.

\section{MATERIAL AND METHODS}

\section{Animals and granulosa cell sampling}

ICR mice were obtained from Qing Long Shan Co., Animal Breeding Center Nanjing, China. Four-week-old female mice were administered an intraperitoneal injection of FSH (10, 10, 5, and 5 IU; Ningbo Second Hormone Factory, China) 4 times every 12 h. Granulosa cells were collected by puncture of the dominant ovarian follicle $(>200 \mu \mathrm{m})$ of the left ovary at 48 , 72 , and $96 \mathrm{~h}$ after the first FSH injection. For real-time quantitative polymerase chain reaction 
(PCR), 20 IU FSH was administered to injected mice $6 \mathrm{~h}$ before the 72- and 96-h extracted granulosa cell treatments, hereafter termed 72-66 and 96-90 h, respectively. Right ovaries were fixed in $4 \%$ paraformaldehyde for the terminal deoxynucleotidyl transferase dUTP nickend labeling (TUNEL) assay.

\section{RNA extraction and cDNA synthesis}

Total RNA was extracted from granulosa cells using TRIzol ${ }^{\circledR}$ Reagent (15596-018; Invitrogen, Carlsbad, CA, USA) according to the manufacturer protocol. RNA concentrations were measured by spectrophotometry $\left(\mathrm{OD}_{260} / \mathrm{OD}_{280}\right)$, and RNA integrity was evaluated by electrophoresis using $1 \%$ formaldehyde denaturing agarose gel. The reverse transcription (RT) of total RNA was performed using a RevertAid ${ }^{\mathrm{TM}}$ RT reagent kit (EP0441; Fermentas) in a $25-\mu \mathrm{L}$ reaction mixture according to the manufacturer protocol. The $25-\mu \mathrm{L}$ mixture contained $10 \mu \mathrm{L}$ total RNA, $0.5 \mu \mathrm{L}$ RevertAid ${ }^{\mathrm{TM}}$ RT Enzyme, $5 \mu \mathrm{L}$ 5X RevertAid buffer, $1 \mu \mathrm{L} 50 \mathrm{mM}$ oligo (dT) ${ }_{18}$ primer, $0.5 \mu \mathrm{L}$ RNase inhibitor, $2 \mu \mathrm{L} 10 \mathrm{nM}$ dNTP mixture, and $6 \mu \mathrm{L} 0.1 \%$ DEPC water. The reaction conditions consisted of two steps: first, $65^{\circ} \mathrm{C}$ for $5 \mathrm{~min}$ and then $-20^{\circ} \mathrm{C}$ for $10 \mathrm{~min}$ to break the secondary structures of RNA; second, $42^{\circ} \mathrm{C}$ for $60 \mathrm{~min}$ followed by $70^{\circ} \mathrm{C}$ for $10 \mathrm{~min}$. The cDNA (RT products) solutions were diluted 10- to 20 -folds and then stored at $20^{\circ} \mathrm{C}$ for quantification by real-time quantitative PCR.

\section{Primer design}

Primers for relevant apoptosis genes (caspase-8, caspase-9, caspase-3, FasL, and BIM) were designed by the Primer 5 software (Table 1). Glyceraldeyhyde-3-phosphate dehydrogenase was used as an internal control. In this study, the amplification products of all the primers had single bright bands of the expected size, and melting-curve analysis showed only one peak.

\begin{tabular}{|c|c|c|c|}
\hline Gene name (GenBank No.) & Primer sequence $\left(5^{\prime} \rightarrow 3^{\prime}\right)$ & Size (bp) & Annealing temperature $\left({ }^{\circ} \mathrm{C}\right)$ \\
\hline Casp8 & F: GCTGTATCCTATCCCACG & 181 & 55 \\
\hline (NM_009812.2) & R: TCATCAGGCACTCCTTT & & \\
\hline Casp 9 & F: GCCCGTGGACATTGGTTC & 244 & 58 \\
\hline (NM 015733.4) & R: TGGCAGTCAGGTCGTTCTTC & & \\
\hline Casp 3 & F: ACAGCACCTGGTTACTATTC & 255 & 54 \\
\hline (NM 009810.2) & R: CAGTTCTTTCGTGAGCAT & & \\
\hline $\mathrm{BIM}^{-}$ & F: TATGGAGAAGGCATTGAC & 207 & 56 \\
\hline (NM_207681.2) & R: TGTGGTGATGAACAGAGG & & \\
\hline FasL $^{-6}$ & F: GGGTCTACTTACTACCTCAC & 192 & 57 \\
\hline (NM 001205243.1) & R: CCCTCTTACTTCTCCGTTA & & \\
\hline GAPDH & F: ATGGTGAAGGTCGGTGTGAACG & 235 & 58 \\
\hline (NM 008084.2) & R: CTCGCTCCTGGAAGATGGTGATG & & \\
\hline
\end{tabular}

\section{Real-time quantitative PCR analysis}

After RT, a real-time quantitative PCR gene expression assay, using the ABI 7300 (Applied Biosystems, USA) with SYBR Green I, was performed. Each quantitative PCR was performed with SYBR Premix Ex Taq (DRR420A; TaKaRa) in a $20-\mu \mathrm{L}$ reaction mixture according to the manufacturer protocol. Each PCR mixture contained $10 \mu \mathrm{L} 2 \mathrm{X}$ SYBR Premix Ex Taq, $0.4 \mu \mathrm{L}$ forward primer, $0.4 \mu \mathrm{L}$ reverse primer, $0.4 \mu \mathrm{L}$ ROX reference dye, $6.8 \mu \mathrm{L}$ 
sterile water, and $2 \mu \mathrm{L} \mathrm{cDNA}$ solution. Controls for each primer set containing no cDNA were included on each plate. Three replicates of cDNA from each granulosa cell sample were performed for each gene.

\section{Detection of apoptosis in granulosa cells of dominant ovarian follicles by TUNEL assay}

Ovaries were embedded in paraffin after a 12 -h fixation in $4 \%$ paraformaldehyde. Ovary paraffin sections were used for the TUNEL assay (In situ Cell Death Detection Kit, Fluorescein, Lot No. 12486400; Roche, Mannheim, Germany). TUNEL labeling was applied to detect DNA fragmentation in granulosa cells of dominant ovarian follicles from the different treatment groups according to the manufacturer protocol. The TdT enzyme was not added to the negative control, and the other processes remained the same. Images were obtained under a laser confocal microscope (Zeiss, Oberkochen, Germany).

\section{Statistical analysis}

Data are reported as means \pm SEM. Statistical differences were analyzed by one-way analysis of variance using the SPSS version 16.0 software (SPSS Inc., Chicago, IL, USA). P values of less than 0.05 were considered to indicate statistical significance.

\section{RESULTS AND DISCUSSION}

\section{Time-course changes in FSH-stimulated granulosa cells from dominant ovarian follicles}

FSH was injected intraperitoneally to promote follicular growth and maturation. Human chorionic gonadotropin was not injected at $48 \mathrm{~h}$ after the first FSH injection, as it could effectively inhibit ovulation. Granulosa cell apoptosis did not occur at 48 and $72 \mathrm{~h}$ after the first FSH injection. Granulosa cells in dominant follicles were mostly TUNEL-negative, but those in dominant follicles were significantly TUNEL-positive at $96 \mathrm{~h}$ (Figure 1A-D).

\section{Effect of FSH in rescuing granulosa cells from apoptosis in dominant ovarian follicles}

Granulosa cell apoptosis is the main factor causing follicular atresia in mammals (Matsuda-Minehata et al., 2008). In rabbits, FSH has no effect on apoptosis of isolated granulosa cells cultured in vitro (Maillet et al., 2002), whereas in rats, pigs, and cows, FSH attenuates apoptosis in cultured isolated granulosa cells in vitro (Zhang et al., 2011).

To study the effect of rescue by FSH from granulosa cell apoptosis in dominant follicles, 20 IU FSH was administered to injected mice $6 \mathrm{~h}$ before the 72- and 96-h extracted granulosa cell treatments, termed 72-66 and 96-90 h, respectively (Figure 2A). Granulosa cells in dominant follicles were TUNEL-negative at 72-66 and 96-90 $\mathrm{h}$ after the first FSH injection (Figure 2B and C), whereas they were TUNEL-positive at $96 \mathrm{~h}$. Another two groups of ovarian paraffin sections were made at 102 and $102-96 \mathrm{~h}$ for the TUNEL assay, and both were TUNEL-positive (Figure 2D and E). We also prepared ovarian paraffin sections at 78, 84, and $90 \mathrm{~h}(\mathrm{~N}=3$ /group) after the first FSH injection for the TUNEL assay. As a result, all groups were TUNEL-negative, whereas granulosa cell apoptosis in dominant follicles occurred dramatically between 90 and $96 \mathrm{~h}$ after the first FSH injection. FSH rescued the granulosa cells from apoptosis before the DNA could be cut into fragments by endonucleases. 


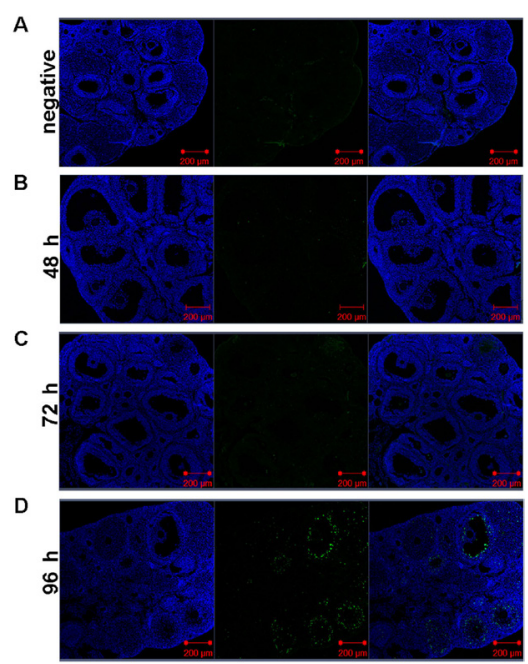

Figure 1. Time-course changes in granulosa cells of dominant ovarian follicles stimulated by FSH. A.-D. Changes $(48,72$, and $96 \mathrm{~h})$ in granulosa cells of dominant follicles after the first FSH injection by TUNEL assay. Similar results were obtained in 5 experiments.
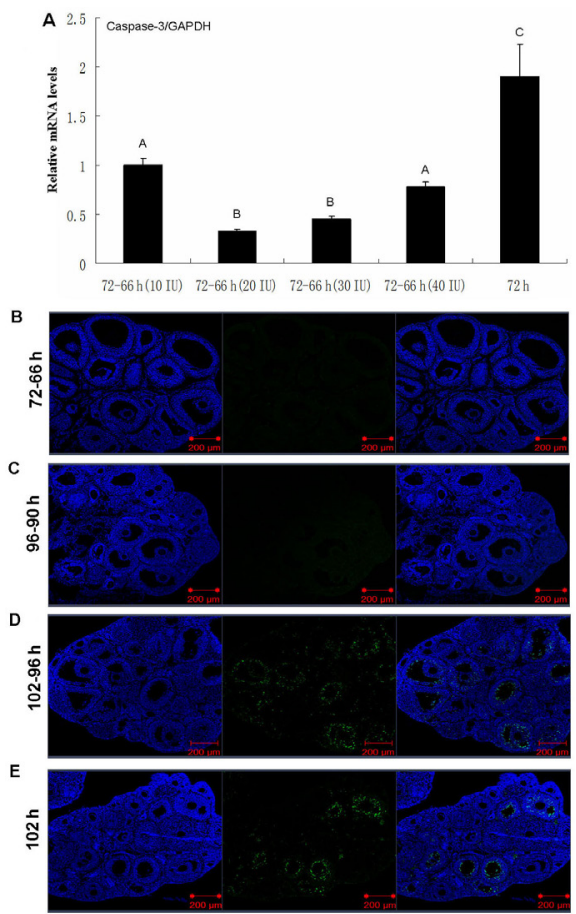

Figure 2. Effect of FSH on rescue from apoptosis in granulosa cells of dominant ovarian follicles by TUNEL assay. A. Different FSH doses were administered to mice at $66 \mathrm{~h}$ after the first FSH injection for efficiency ( $\mathrm{N}=7$ /group); the mean value in the 72-66 h (10 IU) group was set to 1 . Graph values are reported as means \pm SEM. Values indicated by different letters are significantly different $(\mathrm{P}<0.05)$. B.-E. Effect of FSH on granulosa cell apoptosis. Similar results were obtained in 5 experiments. We also prepared ovarian paraffin sections for the TUNEL assay at 78,84 , and $90 \mathrm{~h}(\mathrm{~N}=3$ /group) after the first FSH injection. All groups were TUNEL-negative. 


\section{Time-course changes in relevant granulosa cell apoptosis genes in dominant ovarian follicles}

The BIM, caspase-3, and caspase-9 mRNA expression levels were significantly lower after the 20 IU FSH treatment at 72-66 and 96-90 h, compared with that at 72 and $96 \mathrm{~h}(\mathrm{P}<$ 0.05 ) (Figure $3 \mathrm{~A}$ and $\mathrm{B})$. The caspase- 8 and FasL mRNA levels did not change significantly in any group (Figure $3 \mathrm{~A}$ and $\mathrm{B}$ ).
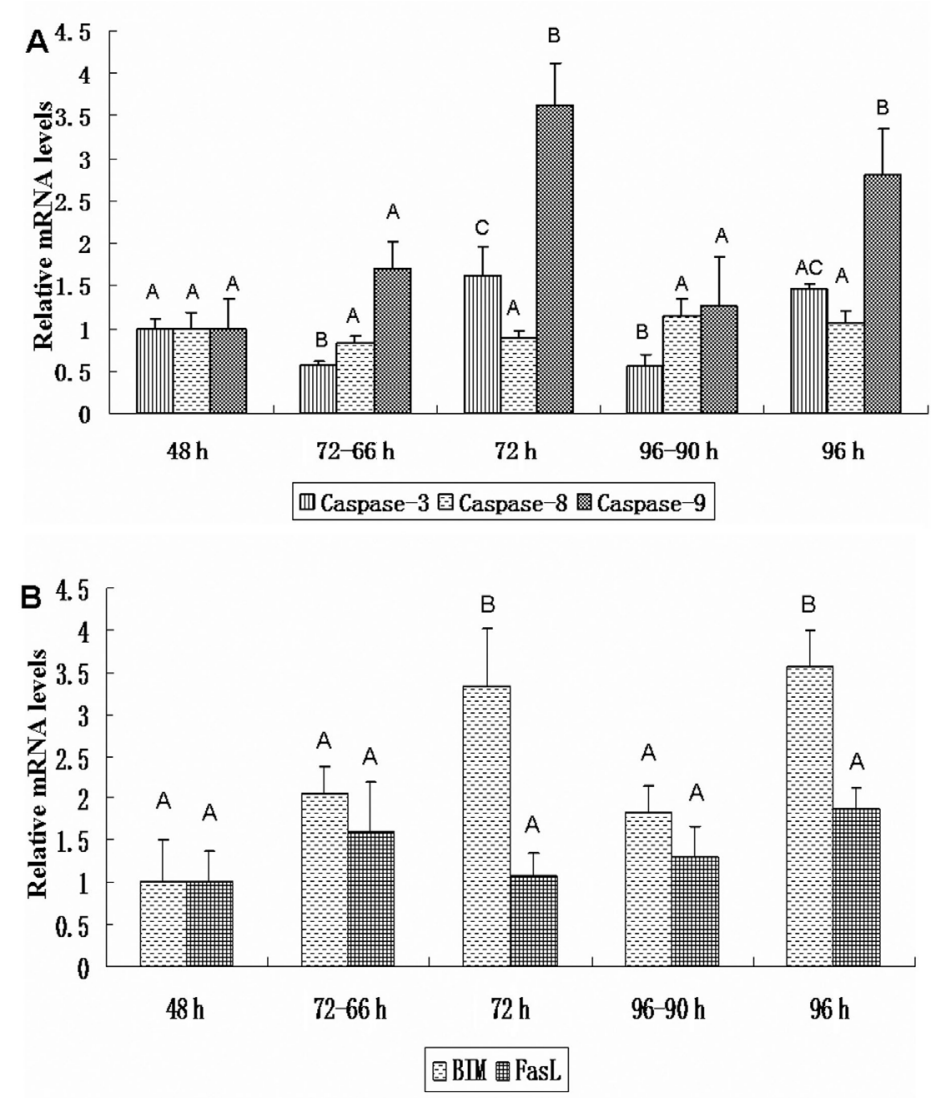

Figure 3. Time-course changes in relevant granulosa cell apoptosis genes of dominant ovarian follicles. A. and B. Time-course changes in the mRNA levels of relevant apoptosis genes at 48, 72-66, 72, 96-90, and $96 \mathrm{~h}(\mathrm{~N}=$ $7 /$ group). The mean value in the 48 -h group was set to 1 . Values indicated by different letters are significantly different $(\mathrm{P}<0.05)$. Graph values are reported as means $\pm \mathrm{SEM}$.

Mitochondrial apoptosis is one of the major causes of cell death (Borutaite, 2010) and is initiated by dissipation of the mitochondrial membrane potential (Jang and Surh, 2003). Overexpression of BIM can induce cytochrome $c$ release, and apoptosis (Harris and Johnson Jr., 2001; Whitfield et al., 2001). Mitochondrial apoptosis causes transport of cytochrome $c$ from the mitochondrial intermembrane space to the cytosol, where it binds procaspase- 9 and Apaf-1 to form active caspase- 9 , which activates executioner caspase- 3 to lead to apoptosis 
(Hengartner, 2000; McStay et al., 2008). Upregulation of death receptor ligands such as FasL activates the initiator of caspase- 8 and subsequent activation of the executioner caspase- 3 and -7, leading to apoptosis (Nagata and Golstein, 1995; Lee et al., 1997; Adams and Cory, 1998). Accordingly, FSH down-regulated BIM, caspase-9, and caspase-3 mRNA levels in granulosa cells of dominant follicles, whereas caspase- 8 and FasL mRNA levels did not change significantly in any group. As a result, FSH prevented atresia in dominant follicles possibly by inhibiting the mitochondrial apoptosis pathway. The BIM, caspase-3, and caspase- 9 mRNA levels between 72 and $96 \mathrm{~h}$ did not change significantly, but TUNEL results indicated that if the dominant follicle failed to ovulate, then mRNA levels of relevant apoptosis genes were upregulated after $48 \mathrm{~h}$, and granulosa cell apoptosis and follicular atresia occurred. The mechanism of how FSH inhibits mitochondrial apoptosis is still unclear. Thus, investigation of the action of FSH on mitochondrial apoptosis could aid in the understanding of granulosa cell apoptosis and follicular atresia.

\section{CONCLUSION}

FSH prevented apoptosis of granulosa cells in early atretic follicles, when relevant apoptosis genes were upregulated. However, FSH could not rescue granulosa cells from apoptosis in late atretic follicles after mitochondrial apoptosis and after the DNA has been cut into fragments by endonucleases. The FSH rescue of granulosa cells from apoptosis and dominant follicle atresia may occur through the inhibition of mitochondrial apoptosis.

\section{ACKNOWLEDGMENTS}

Research supported by a grant from a key project of the Chinese National Program for Fundamental Research and Development (“973” Program 2007 \#CB947403 and 2014 \#CB138502).

\section{REFERENCES}

Adams JM and Cory S (1998). The Bcl-2 protein family: arbiters of cell survival. Science 281: 1322-1326.

Asahara S, Sato A, Aljonaid AA and Maruo T (2003). Thyroid hormone synergizes with follicle stimulating hormone to inhibit apoptosis in porcine granulosa cells selectively from small follicles. Kobe J. Med. Sci. 49: 107-116.

Berry D (2007). Molecular animation of cell death mediated by the fas pathway. Sci. STKE 2007: $\operatorname{tr} 1$.

Borutaite V (2010). Mitochondria as decision-makers in cell death. Environ. Mol. Mutagen. 51: 406-416.

Engelberg-Kulka H, Amitai S, Kolodkin-Gal I and Hazan R (2006). Bacterial programmed cell death and multicellular behavior in bacteria. PLoS Genet. 2: e135.

Gilley J, Coffer PJ and Ham J (2003). FOXO transcription factors directly activate bim gene expression and promote apoptosis in sympathetic neurons. J. Cell Biol. 162: 613-622.

Harris CA and Johnson EM Jr (2001). BH3-only Bcl-2 family members are coordinately regulated by the JNK pathway and require Bax to induce apoptosis in neurons. J. Biol. Chem. 276: 37754-37760.

Hengartner MO (2000). The biochemistry of apoptosis. Nature 407: 770-776.

Hunzicker-Dunn M and Maizels ET (2006). FSH signaling pathways in immature granulosa cells that regulate target gene expression: branching out from protein kinase A. Cell Signal. 18: 1351-1359.

Jang JH and Surh YJ (2003). Protective effect of resveratrol on $\beta$-amyloid-induced oxidative PC12 cell death. Free Radic. Biol. Med. 34: 1100-1110.

Jiang JY, Cheung CK, Wang Y and Tsang BK (2003). Regulation of cell death and cell survival gene expression during ovarian follicular development and atresia. Front. Biosci. 8: d222-d237.

Kaipia A and Hsueh AJ (1997). Regulation of ovarian follicle atresia. Annu. Rev. Physiol. 59: 349-363. 
Kroemer G and Martin SJ (2005). Caspase-independent cell death. Nat. Med. 11: 725-730.

Layman LC and McDonough PG (2000). Mutations of follicle stimulating hormone- $\beta$ and its receptor in human and mouse: genotype/phenotype. Mol. Cell. Endocrinol. 161: 9-17.

Lee J, Richburg JH, Younkin SC and Boekelheide K (1997). The Fas system is a key regulator of germ cell apoptosis in the testis. Endocrinology 138: 2081-2088.

Maillet G, Bréard E, Benhaïm A, Leymarie P, et al. (2002). Hormonal regulation of apoptosis in rabbit granulosa cells in vitro: evaluation by flow cytometric detection of plasma membrane phosphatidylserine externalization. Reproduction 123: 243-251.

Manabe N, Imai Y, Kimura Y, Myoumoto A, et al. (1996). $\mathrm{Ca}^{2+} / \mathrm{Mg}^{2+}$-dependent endonuclease but not $\mathrm{Ca}^{2+}$-dependent, $\mathrm{Mg}^{2+}$-dependent or cation-independent endonuclease is involved in granulosa cell apoptosis of pig atretic follicles. J. Reprod. Dev. 42: 247-253.

Manabe N, Matsuda-Minehata F, Goto Y, Maeda A, et al. (2008). Role of cell death ligand and receptor system on regulation of follicular atresia in pig ovaries. Reprod. Domest. Anim. 43 (Suppl 2): 268-272.

Matsuda-Minehata F, Maeda A, Cheng Y, Sai T, et al. (2008). Regulation of granulosa cell apoptosis by death ligandreceptor signaling. Anim. Sci. J. 79: 1-10.

McStay GP, Salvesen GS and Green DR (2008). Overlapping cleavage motif selectivity of caspases: implications for analysis of apoptotic pathways. Cell Death Differ. 15: 322-331.

Nagata S and Golstein P (1995). The Fas death factor. Science 267: 1449-1456.

Sai T, Goto Y, Yoshioka R, Maeda A, et al. (2011). Bid and Bax are involved in granulosa cell apoptosis during follicular atresia in porcine ovaries. J. Reprod. Dev. 57: 421-427.

Schwartz LM, Smith SW, Jones ME and Osborne BA (1993). Do all programmed cell deaths occur via apoptosis? Proc. Natl. Acad. Sci. U. S. A. 90: 980-984.

Smith CC and Yellon DM (2011). Necroptosis, necrostatins and tissue injury. J. Cell. Mol. Med. 15: 1797-1806.

Wajant H (2002). The Fas signaling pathway: more than a paradigm. Science 296: 1635-1636.

Whitfield J, Neame SJ, Paquet L, Bernard O, et al. (2001). Dominant-negative c-Jun promotes neuronal survival by reducing BIM expression and inhibiting mitochondrial cytochrome c release. Neuron 29: 629-643.

Yang MY and Rajamahendran R (2000). Morphological and biochemical identification of apoptosis in small, medium, and large bovine follicles and the effects of follicle-stimulating hormone and insulin-like growth factor-I on spontaneous apoptosis in cultured bovine granulosa cells. Biol. Reprod. 62: 1209-1217.

Zhang C, Xia G and Tsang BK (2011). Interactions of thyroid hormone and FSH in the regulation of rat granulosa cell apoptosis. Front. Biosci. 3: 1401-1413. 